Erratum

\title{
Erratum to "Modelling the flow cytometric data obtained from unperturbed human tumour cell lines: parameter fitting and comparison" [Bull. Math. Biol. 67 (2005) 815-830]
}

\author{
Britta Basse $^{\mathrm{a}, *}$, Bruce C. Baguley ${ }^{\mathrm{b}}$, Elaine S. Marshall ${ }^{\mathrm{b}}$, \\ Graeme C. Wake ${ }^{c}$, David J.N. Wall ${ }^{\mathrm{d}}$

\begin{abstract}
a Max Planck Institute for Mathematics in the Sciences, Inselstrasse 22-26, 04103 Leipzig, Germany $\mathrm{b}^{\mathrm{b}}$ Auckland Cancer Society Research Centre, Faculty of Medical and Health Sciences, University of Auckland, Private Bag 92019, Auckland, New Zealand

${ }^{\mathrm{c}}$ Centre for Mathematics in Industry, Massey University at Albany, Private Bag 102 904, North Shore MC, Auckland, New Zealand

${ }^{\mathrm{d}}$ Department of Mathematics and Statistics, University of Canterbury, Private Bag 4800, Christchurch, New Zealand
\end{abstract}

The publisher regrets that in the above article the title was printed incorrectly. It is now reproduced correctly, above.

DOI of original article: 10.1016/j.bulm.2004.10.003.

* Corresponding author.

E-mail addresses: britta.basse@paradise.net.nz (B. Basse), b.baguley@auckland.ac.nz (B.C. Baguley), e.marshall@auckland.ac.nz (E.S. Marshall), g.c.wake@massey.ac.nz (G.C. Wake), David.Wall@canterbury.ac.nz (D.J.N. Wall). 